\title{
The spirit of a giant
}

\author{
G. Srinivasan \\ Raman Research Institute (Retired), 190, I Main Road, I Block, BEL Layout, Vidyaranyapura, Bengaluru 560 097, India
}

EVERY now and then one encounters a larger than life person - an extraordinary individual who inspires you and enriches your life. Satish Dhawan was one such.

I first met him in the first week of March, 1976, a few days after I joined the Raman Research Institute (RRI). He was the Chairman of RRI and sent word that he would like to meet me (at that time, he was also the Director of the Indian Institute of Science and the Chairman of ISRO). Since I knew nothing about him, I met S. Ramaseshan to learn more about Satish Dhawan. Ramaseshan invited me to walk with him in the garden of the Raman Institute. He said, 'The best way for me to describe Dhawan is in the following manner. There have been very few men of conscience in recent times, persons who never compromised certain values which they considered as absolute values. Gandhi was a supreme example of such a person... You see that tree there. That is where C. $V$. Raman was cremated and the tree is his memorial; he was another one of them. Satish Dhawan is in the same mould.'

My meeting with Dhawan was short. He briefed me about the history of RRI. Then he said, 'As far as research goes, you are free to do what you wish. But remember this - you have the responsibility to be true to the values which were dear to Raman. He fiercely guarded the autonomy and academic freedom of the Institute. You, and others who work here, must do the same. The autonomy of this institute is its greatest asset.'

During the next twenty-five years I had the privilege of getting to know him well. Satish Dhawan was, of course, a great institution builder; J. R. D. Tata was his inspiration. The preeminent status of the Indian Institute of Science is largely due to the academic structures he created during the nearly twenty-year period during which he presided over it. His pioneering role in creating the very large network of centres under the auspices of ISRO is legendary; that ISRO exemplifies excellence and reliability can be traced back to the structures and procedures he set up. Since others will elaborate on his association with IISc and ISRO, I shall concentrate on some aspects of his unique personality that may not be generally known. Naturally, my impressions are based on my personal interactions with him. Over the years, they were largely centred on the RRI, the Indian Academy of Sciences, and the Indian National Trust for Art and Cultural Heritage (INTACH). I feel that the best way to

*e-mail: gsrini1942@gmail.com bring out his values, his personality, and his priorities, is to recall some conversations with him. And these are chosen at random.

\section{Raman Research Institute}

Raman founded his own institute in 1948 to coincide with his retirement from the IISc. For an excellent historical account, I refer the reader to Journey into Light by G. Venkataraman. Soon after Raman's death in 1970, the second chapter of this institute began with the enthusiastic support of Prime Minister Indira Gandhi. As Dhawan told me during our first meeting, it would have been natural for RRI to come under the umbrella of the Department of Space. But he wanted RRI to be the first autonomous institute under the newly formed Department of Science and Technology (DST). As he put it, 'It would kill two birds with one stone if the DST and RRI grew up symbiotically'; he wanted the department dealing with science and technology to have a very different character compared to the typical government department. This was reflected in the way the bylaws of the institute were framed, and the way in which he structured the Governing Council of RRI (of which he was the Chairman for over twenty years). He patterned the Council after the way Homi Bhabha had set up the Atomic Energy Commission, and the way the Space Commission is constituted. The Secretary of DST was a member of the RRI Council and its Finance Committee; the Finance Secretary

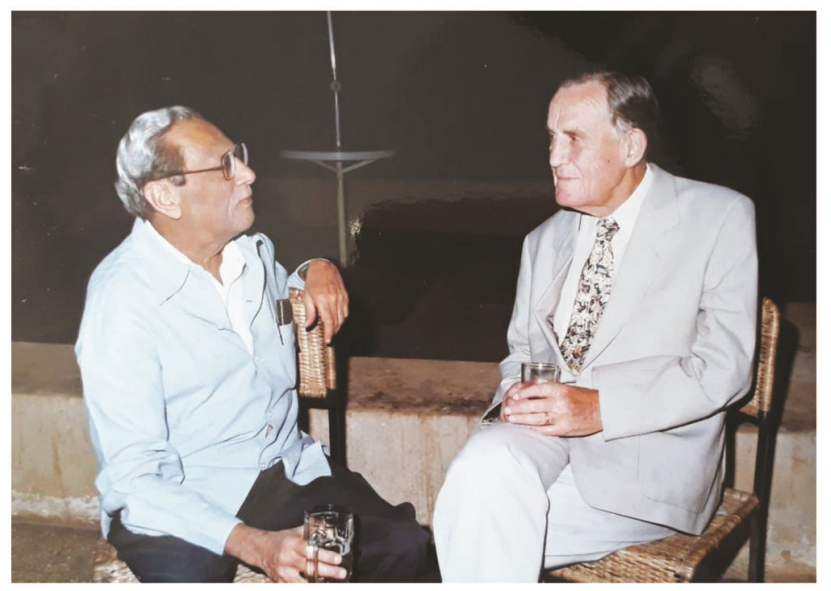

Dhawan with the famous astronomer Hanbury Brown (photo taken at RRI in 1994). Hanbury Brown was the first Raman Professor of the Academy (1974). 
of DST was also a member. Since the highest officials of the DST were a party to decisions taken by the Council, Dhawan insisted that there be no further reviews of the Council's decisions in Delhi. Also, throughout his tenure as the Chairman of the RRI Council from 1974 to 1999 , he insisted that the Secretary of DST personally attended the meetings; Dhawan did not permit any 'nominee of the Secretary' to represent the Secretary at the Council meetings! Dhawan fiercely protected the autonomy of the institute.

I was fascinated by another aspect of his vision. Although he was at the same time the Director of IISc, the Chairman of RRI and the Chairman of ISRO, he approached each of these organizations very differently. As for IISc and RRI, his attitude was 'let a thousand flowers bloom'; he did not wish to circumscribe research activities with any constraints. But his views on the mandate of the Space Department, and its accountability to the nation, were very different. While he firmly believed that science should be at the core of any space programme (as the name Indian Space Research Organization indicates), Dhawan shared Vikram Sarabhai's vision that in a country like India the main thrust of the space programme should be for the welfare of its people.

\section{The Indian Academy of Sciences}

Another institution Dhawan was deeply concerned about was the Indian Academy of Sciences, founded by C. V. Raman in 1934. Prior to the founding of the Academy, Raman had argued in a series of Editorials in Current Science that whereas individual Indian scientists had achieved international recognition due to their indefatigable efforts, as a 'scientific community' India had not achieved the status of even the smaller nations of Europe. He reasoned that in order for this to change, results of scientific investigations in India should be showcased in the journals of an 'Academy of Science'. This was the rationale for the founding of the Indian Academy of Sciences in 1934. Raman was its President till he died in November 1970. Naturally, the main activity of the Academy till then was the publication of journals. Raman took all the decisions, and there was not much room for widespread discussion among its Fellows.

Clearly, things had to change in the post-Raman era. Two things happened. Soon after Raman passed away, the Council presided over by T. S. Sadasivan, honoured Raman's wish and formally separated the activities of the RRI and the Academy; all movable and immovable assets were split between the newly created RRI Trust and the Academy.

In 1972, Satish Dhawan stressed that while publication of journals is important, there was a need to enlarge and better define the objective of the Academy in a comprehensive manner, and make it more relevant and effective in the contemporary context. In short, Dhawan argued that a Manifesto was needed which would spell out the 'role of the academy'.

The Council concurred with Dhawan, and a committee consisting of Satish Dhawan (Convenor), Raja Ramanna, R. M. Varma and S. Varadarajan drafted the Manifesto which was formally approved by the Council in April 1975. Since then, the 'Role of the Academy' is printed in the opening pages of its Year Book.

In 1986, I was elected to the Council and was to serve as its Secretary (Sharat Chandra was the other Secretary). Dhawan had a second one-on-one meeting with me in the Council Room of RRI, where the Academy Council also met. He quizzed me on what my priorities would be as the Secretary of the Academy. After listening to me, he said several things.

The first thing he said was this. 'As the Secretary of the Academy, send a letter to every newly elected Fellow reminding them that being elected to the Academy should not be viewed as "an honour"; rather, it should be viewed as an opportunity to serve the Academy.' It might be of interest to recall the following. Dhawan was elected to the Academy in January 1970. Interestingly, he was proposed for the Fellowship by C. V. Raman himself. Within a year of Raman's passing away, Dhawan was deeply involved in the affairs of the Academy. He initiated discussions to expand the role of the Academy beyond the publication of journals.

Next, pointing to the portrait of a formidable looking Raman on the wall, he said to me, 'Remember that he will be looking at everything you do. Don't sell your soul to the government just because the Academy accepts funds from them!'

He went on. He ventured to suggest that the time had come for the Academy to take a considered stand on important issues - issues of interest and concern to the public. He encouraged the idea of the Academy coming out with well researched documents, together with recommendations, along the lines of the 'White Papers' brought out, for example, by the Royal Society of London. He felt that an Academy of Science would become irrelevant if all it did was to elect Fellows and publish research journals. Clearly, Dhawan did not share Raman's view that 'it is the people in ivory towers who matter' (This was apparently his response when Nehru once commented that scientists should not sit in ivory towers).

This conversation with Dhawan did have some effect in the years to come. For example, during its annual meetings, the Academy organized Mini Symposia and Public Lectures on topics such as 'The Narmada Valley Project', 'The safety of India's Nuclear Programme', etc. The speakers included both government representatives, as well as social activists.

During the eighteen years I served on the Council of the Academy, there were numerous situations where the government had to be pushed back. To cite some 


\section{SATISH DHAWAN BIRTH CENTENARY}

examples, the Council rejected efforts to have a DST representative on its Council; similarly, the Council rejected efforts to have a DST representative on its 'Buildings Committee'; the Council insisted that it alone would define what will come under the purview of the Right To Information Act, etc.

Dhawan felt very strongly that the scientific documents (or 'White Papers') produced by scientists should be available in the public domain. He was incensed by the tendency of the government to declare many documents as 'Classified'. For example, a detailed scientific study on 'The ground water table in Bangalore', or the document quantifying 'The amount of water flowing into the Arabian Sea in the Narmada Estuary', were 'Classified' by the government, and hence not available in the public domain! He stressed that the Academy should do everything it can to persuade the government to 'declassify' such data. In response to these comments by Satish Dhawan, the Academy set up a high-level panel to address this problem.

It was fascinating to watch this great man in action from a ring side seat. Apart from his leadership qualities, what made him so very special was his humaneness, compassion and his sense of social justice. Indeed, his success as an institutional builder and as a leader, was in large measure due to these qualities (like in the case of the great J. R. D. Tata). I wish to cite a few examples to illustrate these qualities.

Sometime during the 1980 s, I ran into him one early morning at a doctor's clinic in Kumara Park. I was struck by the fact that some four or five kids got out of his car. Noticing the surprise on my face, he said, 'These kids live in the slum behind our house, and got bitten by a dog. It is important that they take a full course of anti-rabies injections. Since their parents won't bother, I bring them here every morning and make sure that they get their shots.' It was characteristic of him that he drove his old FIAT Milli Cento, and did not come in the chauffeur

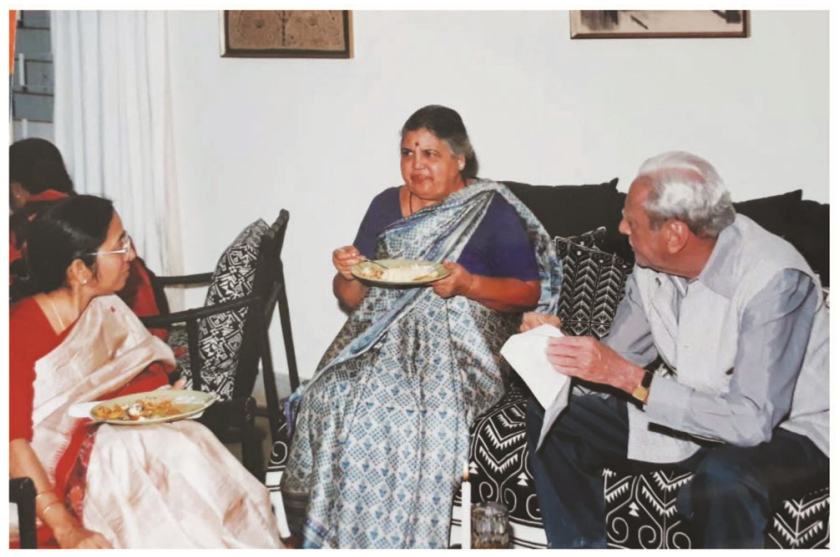

Satish and Nalini Dhawan (centre) at a get together in Raman Research Institute. driven ISRO car which would later take him to the Department of Space.

In 1994, I was supervising the construction of the Diamond Jubilee Building of the Indian Academy of Sciences. One day, Dhawan called and reminded me that according to law, the contractor was supposed to provide a crèche for the children of the construction workers. He said that since the contractor won't do it, I should take the responsibility of providing some help to the parents of the children. This remark touched my heart. While I couldn't provide a proper crèche for the half a dozen children on the construction site, I did the best I could, such as regularly providing the children food packets, sweets, and new clothes for Ayuda Pooja.

Dhawan felt deeply for the 'wretched of the earth'. He would often talk to me about the pathetic condition of the 'rag pickers', the 'construction workers', the slum dwellers. He really felt for them. He was a true Gandhian at heart.

Apart from matters relating to the RRI and the Indian Academy of Sciences, I sought Dhawan's advice and help in other matters of social importance. During the 1980s and 90s, I represented the RRI (an 'Institutional Member') in the Bangalore chapter of INTACH, an organization set up in 1984 with active support from Prime Minister Indira Gandhi. INTACH got actively involved with various local issues, such as saving the Bangalore Palace Grounds (there was an attempt to sell a major part of the ground - the Polo ground - to property developers), preventing the demolition of the iconic High Court building in Cubbon Park, and many such issues. Invariably, I would meet Satish Dhawan and seek his advice and help whenever a major issue came up. When all else failed, he would personally intervene, and that would generally clinch the issue. Such was the moral authority he commanded. I shall give two examples of such personal interventions by Dhawan.

\section{Bangalore Planetarium}

Many groups had been lobbying for a long time for a Planetarium in Bangalore. Finally, the state government agreed. Unfortunately, the venue that was tentatively chosen was adjacent to the beautiful lake (Sankey Tank) near Indian Institute of Science. This would have wrecked the ecology of the lake. Naturally, various groups were up in arms.

Around the same time, a prime 'triangular plot' adjacent to the Raj Bhavan which belonged to the Defense Ministry was about to be leased, or sold, for a shopping complex. That, too, would have been a terrible decision.

A few of us met Dhawan and appealed to him to intervene in both these cases. A few months later we learnt that both the objectives had been met! The Planetarium was to come up, not near Sankey Tank, but in the triangular 
plot adjacent to Raj Bhavan; there was to be no shopping centre there; the ecology of Sankey Tank would be preserved. Hurray! It transpired that Dhawan had raised this matter with Mrs Indira Gandhi, and subsequently discussed it with Raja Ramanna who was then the Director General of DRDO. Today, both Sankey Tank and the Planetarium attract thousands of visitors every day.

\section{Silent Valley}

The Silent Valley is an evergreen rainforest in the Western Ghats in Palakkad District of Kerala. The Kerala government was planning to build a dam in this valley as part of a hydroelectric project. A well-articulated people's movement to stop this gathered momentum in the 1970s. This movement had support from a very popular science movement in Kerala, the Kerala Shastra Sahitya Parishad (KSSP).

Prime Minister Indira Gandhi was not enthusiastic about the hydroelectric project. She was conscious of the mounting international pressure to abandon it. The Silent Valley was famous for the lion-tailed macaque-the second-most threatened primate in the world. Not surprisingly, the danger to the lion-tailed macaque became the bone of contention during the Silent Valley controversy. While the conservationists wanted its population and habitat protected, the pro-dam groups ridiculed the environmentalists for giving priority to monkeys over human needs. The International Union for Conservation of Nature (IUCN) passed a resolution to preserve the Silent Valley. This brought considerable pressure on the central government. But the Prime Minister's political colleagues in Delhi and Kerala were strongly in favour of the project. But there was strong opposition, too. M. S. Swaminathan (Agriculture Secretary) and Salim Ali (the famous Ornithologist) were among those who conveyed their views to the Prime Minister. Despite these voices of dissent, it looked like the Kerala Chief Minister would have his say. He famously said, 'Environmental protection is the luxury of rich nations. We are a poor country.'

It was at this stage that Satish Dhawan met Mrs Gandhi and expressed his strong opposition to the project. He persuaded her to set up a multidisciplinary committee and seek a comprehensive opinion. A committee, with M. G. K. Menon as Chairman, the renowned ecologist Madhav Gadgil, and a few others as members was set up. Mrs Gandhi accepted the recommendation of this committee and decided to deny permission for the hydro-electric project.

Silent Valley was notified as a National Park on 15 November 1984, a fortnight after her assassination. Prime Minister Rajiv Gandhi inaugurated the park on 7 September 1985.

Satish Dhawan was an outstanding aeronautical and aerospace engineer. He had a special liking for English literature and mathematics. He was a monumental institu- tion builder. But what I found truly awe inspiring about him was his humaneness, concern for the poor and downtrodden, and an intense sense of social responsibility. He believed in doing what is correct, regardless of whether it was perceived as just or not. I vividly recall the occasion when he thundered, 'I will not be rushed into doing what is expedient. Not even God can influence me to do that.'

Satish Dhawan was a philosopher. This came through in every conversation I had with him. After his retirement from IISc and ISRO, I used to meet him in his small office in ISRO Head Quarters. Under the glass top on his table, there were three papers - two selected pages from the Indian Constitution and the third with the following quote from Buddha which sums up his philosophy.

\section{'Be ye lamps unto yourselves \\ Be ye your own reliance \\ Hold to the truth within yourself \\ As to the only lamp'}

The values mentioned above - humaneness, compassion, concern for the poor, social justice - defined his personal life. And that was the source of the incredible moral authority he commanded. Here is an example.

In the early part of 1980 s, there was considerable controversy surrounding the newly created Aeronautical Development Agency (ADA) and the Light Combat Aircraft (LCA) project. At the centre of the controversy was Raj Mahindra, the Chief Designer for the LCA. Raj Mahindra was hired by HAL in 1959. Prior to that he had worked for many years in England and had an exceedingly good reputation as an aircraft designer. Mahindra was married to a British national. He made this known to the concerned authorities when he joined HAL. Successive Directors and Chairmen of HAL were aware of this.

Raj Mahindra's problems began many years later when he retired as the Managing Director of HAL, and was reemployed by the $\mathrm{ADA}$ as the Chief Designer of the

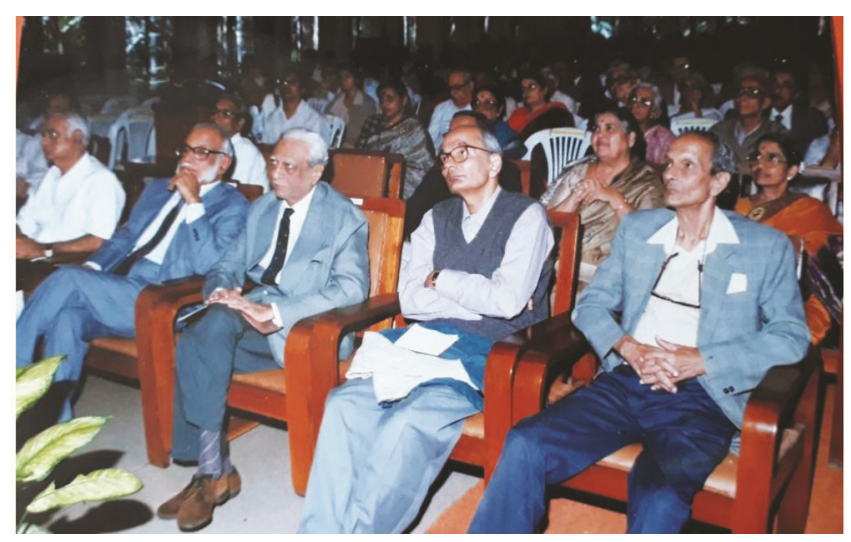

At the Golden Jubilee of Raman Research Institute (1998). From left to right: G. Venkataraman, M. G. K. Menon, Satish Dhawan, A. Jayaraman and S. Ramaseshan. 


\section{SATISH DHAWAN BIRTH CENTENARY}

LCA. Sensational stories started appearing in leading national newspapers about a 'British citizen in a sensitive job'. Not surprisingly, the matter was repeatedly raised in the Parliament. Mahindra's loyalty and patriotism, as well as his educational qualifications, were questioned. The Secretary of Defence Production conducted an enquiry and formally exonerated Raj Mahindra. But the vicious attacks continued in the parliament.

It was at this stage that Dhawan wrote a letter to Prime Minister Indira Gandhi (I had the privilege to read that letter). In that powerfully worded letter, Dhawan defended Raj Mahindra and expressed the view that the country owed Mahindra a public apology. A couple of weeks later, leading newspapers carried an account of the speech made in the parliament by the Defence Minister publicly defending Raj Mahindra.

Such was the moral authority Satish Dhawan commanded.

\section{The spirit of a giant}

In November 1998, Raman Research Institute celebrated its Golden Jubilee. While planning the various events, I consulted Satish Dhawan (Chairman of RRI). This was his advice, 'In 1988, the birth centenary of Raman was celebrated all over the country. A definitive biography highlighting his life and science was published (Journey into Light). Let us not have any "tamasha" now. What we desperately miss today is Raman's indomitable spirit. Invite $G$. Venkataraman, and ask him to remind us about
Raman's values.' Following Dhawan's advice, the sole event to mark the Golden Jubilee of RRI was G. Venkataraman's lecture entitled The Spirit of a Giant (I thought it would be appropriate to borrow that title for this article).

Today, our institutions are being systematically threatened. Their autonomy is being severely eroded. Our environment is being ravaged. Our history is being rewritten. The pluralism of our society is being undermined. Sadly, there is very little protest, particularly from the scientific community. Silence is complicity.

More than at any other time, we need to remind ourselves of the values which Satish Dhawan epitomized, and his indomitable courage to speak up.

When Dhawan passed away, I requested his family to give me some of his ashes. I had planned to go with my family to Silent Valley and disperse his ashes there. Since I couldn't get the necessary permission, we drove to a lovely spot in the Palani Hills - a spectacular Sholai and a waterfall, with a panoramic view of the Palani Hills. There we dispersed his ashes, sat in our car, turned up the volume full blast, and listened to the great Mass in $B$ Minor by Johann Sebastian Bach.

As we mark the birth centenary of Satish Dhawan, let us celebrate his remarkable life by listening to the Gloria in excelsis from https://www.youtube.com/watch?v= WqXH6Pb2TaA.

doi: $10.18520 / \mathrm{cs} / \mathrm{v} 119 / \mathrm{i} 9 / 1469-1473$ 